\title{
Reversibility of DNA loops exit during single cell gel electrophoresis
}

\author{
K. S. Afanasieva, T. A. Shuvalova, M. O. Zazhytska, A. V. Sivolob \\ Department of General and Molecular Genetics, National Shevchenko University, \\ 64, Volodimirska str., 01033 Kiev, Ukraine \\ sivolob@univ.kiev.ua
}

\begin{abstract}
The kinetics of DNA exit during single cell gel electrophoresis (comet assay) of human lymphocytes has been investigated. The electrophoresis was carried out at neutral pH either in the absence or in the presence of different ethidium bromide concentrations. The demonstrated dependence of the DNA exit efficiency on the ethidium bromide concentration indicates that the comet tail consists of DNA loop domains extended by the electric field. The loop exit is essentially favored when the DNA torsional constraint is relaxed. In contrast, the comet disappearance after the switching off the electric field was observed if some level of the constraint remained in the extended loops. Several possibilities of applications of the revealed effects for improvement of the comet assay are discussed.
\end{abstract}

Key words: comet assay, loop domains, ethidium bromide, DNA torsional constraint.

Introduction. The comet assay is a convenient method widely used for evaluation the level of DNA damage in single cells [1-3]. The assay is based on the preparation of microscope slides of cells, embedded in law-melting agarose, which are then lysed with detergents and high ionic strength. The lysis treatment removes both cellular and nuclear membranes as well as proteins (responsible for the DNA-nuclear matrix interactions). Then the obtained nucleoids [4] are electrophoresed. DNA exits from the lysed cell under the influence of electric field and forms an electrophoretic track, which looks like a comet tail. Formation of such tail is facilitated if different DNA damages occur (as a result of apoptosis, ionizing radiation, free radicals etc.). That is also the reason of wide application of the method.

An essential problem of the approach is a considerable variability of the results obtained in

(C) K. S. AFANASIEVA, T. A. SHUVALOVA,

M. O. ZAZHYTSKA, A. V. SIVOLOB, 2008 different laboratories. Several attempts to standardization of the comet assay conditions have been made [1-3, 5]. Nevertheless the absolute standardization is impossible because the time of electrophoresis is to be adjusted empirically for different electrophoretic devices (usually from 20 to 60 $\min [1-3,5,6])$.

Although the method is very popular, there is still no consensus on how the comet tail is formed [3]. On the one hand, it is obvious that accumulation of single-strand breaks leads to appearance of double-strand breaks. In this case the tail is formed by linear DNA fragments that either keep connection (through one of its ends) with the nuclear matrix or lost it. On the other hand, the relative DNA amount in the tail increases upon accumulation of single-strand breaks while the length of the tail remains the same. Therefore, it has been suggested [7] that the relaxation of supercoiled DNA loops may be the main reason of DNA exit facilitation. Indeed, supercoiling appearing 
in the loop after nucleosome removal during lysis [4] should maintain a compact state of the loops. If there is only one single-strand break in the loop, the supercoiling disappears and it would be easier for DNA to overcome the agarose resistance during electrophoresis.

In this article the proofs of the loop relaxation as the main mechanism of DNA exit in the comet assay are presented. Although the comet assay was initially carried out at neutral $\mathrm{pH}$, now alkaline conditions (at $\mathrm{pH}>13$ ) are used more often [1-3]. Since alkali facilitates DNA damage in sites of apurinization, DNA certainly can not be intact after such treatment. The aim of the present research is investigation of comet tail formation mechanisms, therefore, a neutral version of the comet assay has been used.

The kinetics of comet formation as well as the effect of the loop topology on this kinetics was investigated in our experiments with isolated human lymphocytes. The topological state of DNA lops was influenced by ethidium bromide which is able to unwind the double helix. The observed dependence between the rate of the comet appearance and ethidium bromide concentration clearly demonstrates that the comet tail is formed by the loop domains extended in the electric field. Moreover, the high level of torsional constraint in the extended loops provides the reversibility of the process. The disappearance of the comets was observed after switching off the electric field. Our results allow one to suggest that recording the kinetics of DNA exit (or return) instead of the application of the fixed time of electrophoresis could essentially improve the comet assay.

Materials and methods. The peripheral blood lymphocytes were obtained from finger-prick blood samples taken with a syringe containing heparin from several volunteers. The lymphocytes were isolated immediately with a standard kit (Henx solution, ficol-verografin density gradient, Reakompleks, Russia) according to recommendations of the manufacturer. The lymphocytes isolated by centrifugation in the density gradient were twice washed in $0.15 \mathrm{M} \mathrm{NaCl}$, and $50 \mu \mathrm{l}$ of the suspension were mixed with $100 \mu \mathrm{l}$ of $1 \%$ low-melting point agarose (Sigma, USA) at $\sim 50^{\circ} \mathrm{C} .25 \mu \mathrm{l}$ of the mixture was deposited on a microscope slide, and covered with $1 \%$ high-melting point agarose.

The slides were kept at $4^{\circ} \mathrm{C}$ for $3-5$ min until agarose polymerization is complete and then placed in the lysis solution: $2.5 \mathrm{M} \mathrm{NaCl}, 100 \mathrm{MM}$ EDTA, $10 \mathrm{MM}$ Tris- $\mathrm{HCl} \quad(\mathrm{pH}$ 8.0), 1\% Triton X-100 (Ferak, Germany), which was added directly before use. The cells were exposed to the lysis solution for at least 1 hour at $4^{\circ} \mathrm{C}$. After the lysis the slides were washed by TBE buffer ( 89 мM Tris, $89 \mathrm{мM} \mathrm{H}_{3} \mathrm{BO}_{3}, 2$ мM EDTA, pH 7.5) during 10-15 min.

Several slides were then placed in a horizontal electrophoresis apparatus. Electrophoresis was performed in TBE buffer at $4^{\circ} \mathrm{C}(1 \mathrm{~V} / \mathrm{cm}, 300 \mathrm{~mA})$. Ethidium bromide was added to the electrophoretic buffer in concentrations of $0,5 \times 10^{-5}, 2 \times 10^{-4}$ or $3.5 \times 10^{-4}$ $\mu \mathrm{g} / \mathrm{ml}$. The concentration of ethidium bromide in stock solution was measured spectrophotometrically. To investigate the kinetics of the comet formation, the slides were taken out at different time for further analysis.

To study the reversibility of DNA exit, the electrophoresis was performed with several microscope slides for a long time (at least 1 hour). After that the electric field was switched off and the slides were kept in the same buffer at $4^{\circ} \mathrm{C}$ for different time.

In a series of experiments the lymphocytes were irradiated by X-rays ( 0.25 Gy) with RUM-17 apparatus (Mosrentgen, Russia) and electrophoresed without ethidium bromide.

Each slide was stained with ethidium bromide (5 $\mu \mathrm{g} / \mathrm{ml}$ ) and analyzed with a fluorescence microscope Lumam P3 (LOMO, Russia) connected to a digital camera. To evaluate the comet score (the fraction of the cells with the comet tail) a total 100-200 cells were analyzed on the slide. The relative amount of DNA in the tail was determined using an image analysis software ScionImage (Scion Corporation, USA).

Results and discussion. Several examples of lysed cells as they are visible in fluorescent microscope after electrophoresis are presented in Fig. 1. The images are typical: there were no differences in the comet appearance in all our experiments. The average length of the comet tail is approximately $50 \mu \mathrm{m}$ (the corresponding tail length/nuclear diameter ratio is $\sim 5.5$ ); the relative amount of DNA in the tail (with 


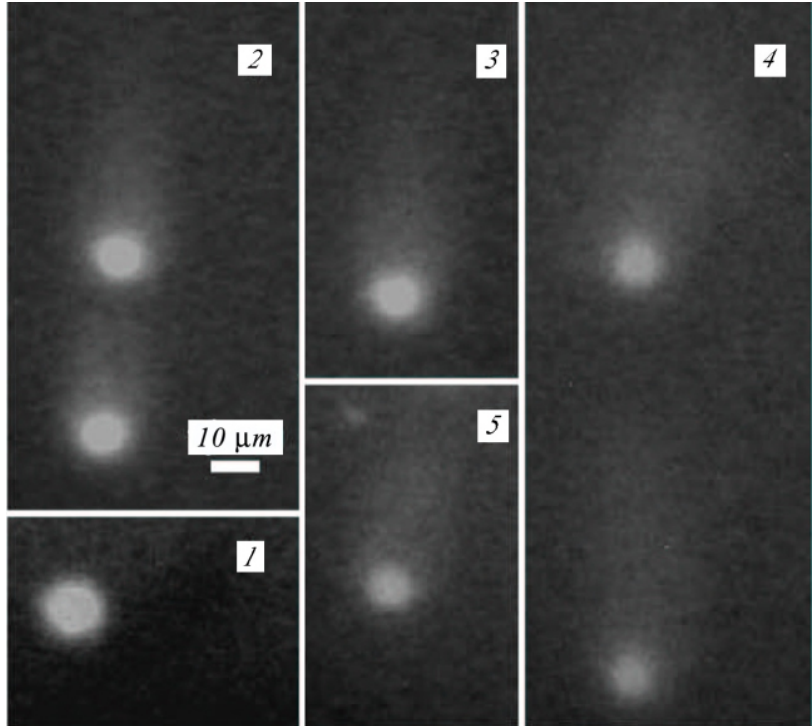

Fig. 1. Fluorescent microscope images of the cells after the comet assay. The representative examples of the cells without (1) and with the comet tails (2-5) are shown.

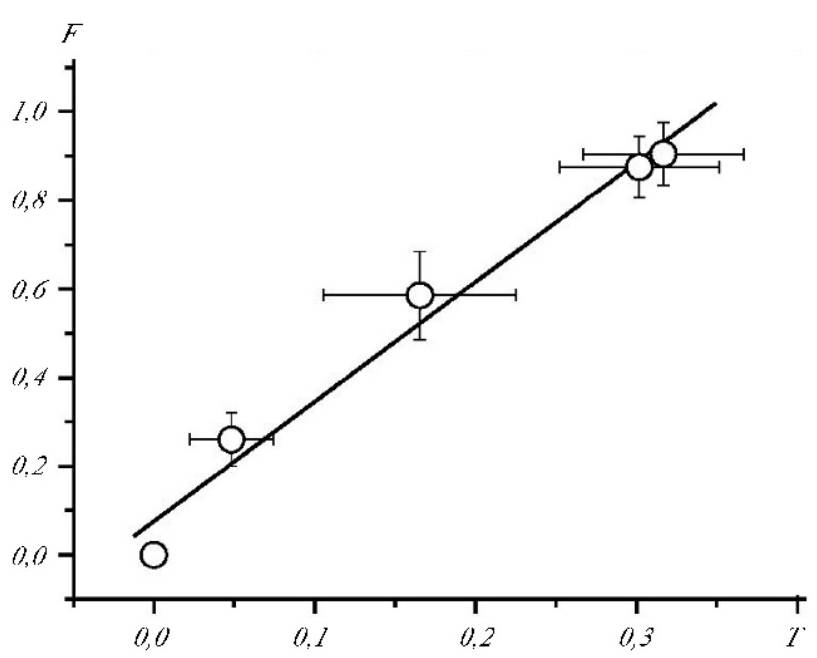

Fig. 2. An example of the linear correlation between the comet score ( $F$, the fraction of the cells with the comet tails) and the average DNA fraction in the tails $(T)$. The results of an experiment in presence of $5 \cdot 10^{-5} \mu \mathrm{g} / \mathrm{ml}$ of ethidium bromide are shown.

respect to the total amount in the comet tail and nucleus) varies from 0 to $35 \%$ depending on the electrophoresis duration.

An increase in the relative amount of DNA in the tail during electrophoresis occurs in parallel with increasing the comet score. As it is shown in the Fig. 2 there is a linear correlation between the two parameters. Thus the comet score can be considered to be proportional to the efficiency of DNA exit in the comet tail.

The data on the kinetics of DNA exit are presented in Fig. 3, $a$. In the absence of ethidium bromide, the comet score is quite low until 30th min of electrophoresis, then it rises and reaches practically $100 \%$ in $120 \mathrm{~min}$. After X-irradiation the comet score reaches high level in $15 \mathrm{~min}$. Thus we can conclude that DNA in non-irradiated lymphocytes is mostly intact and can form the comet tail only when the electric force is applied for a long time.

If DNA is intact, the tail cannot contain anything except for the loops connected to the nuclear matrix by their ends. In addition to the agarose resistance, these loops have to overcome their own torsional constraint to be extended in the comet tail. When all the chromatin proteins are removed after the lysis, negative supercoiling remains in the nuclear DNA. The supercoiling density $\mathrm{y}_{0}$ should be approximately -0.05 (considering 1 supercoil per nucleosome [8] at nucleosome density $1 / 200 \mathrm{bp}$ and DNA helical periodicity $10.5 \mathrm{bp}$ per turn of the double helix). An extension of the loop creates a negative torsional constraint (in the direction of the double helix unwinding). This allows one to expect that a relaxation of this constraint should facilitate the comet tail extension.

The easiest way to relax the negative supercoiling is to unwind the double helix locally due to intercalation of ethidium bromide [9]. Indeed, we observed substantial acceleration of the comet tail formation in the presence of $5 \cdot 10^{-5} \mu \mathrm{g} / \mathrm{ml}$ of ethidium bromide (Fig. 3, a). This concentration, among the other used concentrations (not all of them are presented in Fig. 3), appeared to be the most effective for the facilitation of DNA exit. One can conclude that this concentration approximately corresponds to the total relaxation of the negative supercoiling. The further increase in ethidium bromide concentration (and in the dye binding density, respectively) causes accumulation of positive supercoiling which again slows down the comet formation - even in comparison with the kinetics of DNA exit in the absence of the dye (Fig. 3,a). It should be noted that the described effects unambiguously support the conclusion that DNA is mostly intact in the non-irradiated cells: the loop 


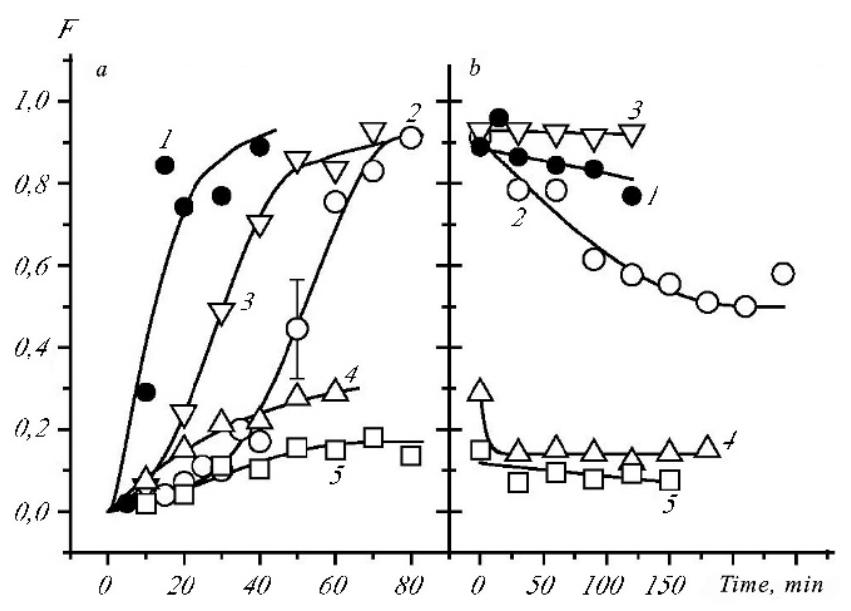

Fig. 3. The comet score as a function of electrophoresis duration (a) and time of incubation in the electrophoretic buffer after switching off the prolonged electrophoresis $(b)$ for irradiated $(\bullet)$ and non-irradiated cells either without $(\circ)$ or in the presence of $5 \times 10^{-5}$ $(\nabla), 2 \times 10^{-4}(\triangle)$ and $3.5 \times 10^{-4}(\square) \mu \mathrm{g} / \mathrm{ml}$ of ethidium bromide. Each point is an average for 3 to 5 independent experiments. The error bar (the standard deviation, shown for only one point in order to clarify the figure) represents the maximal experimental error. The smooth curves are the result of an interpolation.

domains are topologically constrained in the absence of single strand breaks only.

Let us consider the ethidium bromide effects in details. The above-estimated supercoiling density $\sigma_{0}$ changes for the value $\sigma=\sigma_{0}+\sigma_{\mathrm{E}}$, where $\sigma_{\mathrm{E}}=v \theta h / 360^{\circ}$ due to intercalation [10]. In the last equation $v$ is the dye binding density (the number of intercalated molecules per $1 \mathrm{bp}) ; \theta=22^{\circ}[10]$ is the unwinding angle in the intercalation site; $h \approx 10.5 \mathrm{bp} /$ turn is the periodicity of the double helix. Ethidium bromide binding to circular DNA (which is equivalent to the loop domain) is described by equation [9]:

$$
\mathrm{v} / L=K \frac{(1-n \mathrm{v})^{n}}{(1-n \mathrm{v}+\mathrm{v})^{n-1}} \exp \left[2 A\left(\mathrm{v}_{0}-\mathrm{v}\right)\right],
$$

where $L$ is the molar concentration of free dye (in our experiments it is equal to the total concentration of ethidium bromide in the electrophoretic buffer); $K$ is the binding constant; $n \approx 2.5 \mathrm{bp}$ [10] is the size of the binding site; $A \approx 5[9,10]$ is the modified supercoiling force constant; $\mathrm{v}_{0}=-360^{\circ} \sigma_{0} /(\theta \mathrm{h})$ is the binding density corresponding to the total relaxation of initial negative supercoiling. At $\cdot v=\mathrm{U}_{0}$ the exponential term in the equation turns into unity and the equation becomes equivalent to relation describing ethidium bromide binding to linear (or nicked) DNA. If we assume that $5 \times 10^{-5} \mu \mathrm{g} / \mathrm{ml}$ of ethidium bromide corresponds to the point of relaxation (thus the binding density at this concentration $v \approx v_{0}$ and the net supercoiling density $\sigma \approx 0$ ), then according to the equation the binding constant can be estimated as $K \approx 9 \times 10^{5} \mathrm{M}^{-1}$. This value agrees well with the expected one at ionic strength of TBE buffer [10]. Using this $K$ value, one can calculate the net supercoiling density at the two other ethidium bromide concentrations: $\sigma \approx+0.035$ at $2 \times 10^{-4} \mu \mathrm{g} / \mathrm{ml}$ and $\sigma \approx+0.05$ at $3.5 \times 10^{-4} \mu \mathrm{g} / \mathrm{ml}$.

The question is why at almost the same absolute values of the torsional constraint, without the dye and at its concentration of $3.5 \times 10^{-4} \mu \mathrm{g} / \mathrm{ml}$, DNA exit is much slower in the second case (Fig. 3, a). Apparently, the answer arises from the fact that DNA double helix is right-handed: the structural transitions in the direction of the duplex unwinding (the local melting is the simplest of such transitions) occur in negatively supercoiled circular DNA [11]. As a result, the effective level of the torsional constraint decreases. Such effect is impossible in positively supercoiled DNA, while the absolute value of the constraint appears to be higher. In addition, the binding of ethidium bromide to positively supercoiled DNA additionally favors a compact interwined form of the loop $[10,12]$.

Another question as for the dependences presented in Fig. 3, $a$ is related to the comparison of the comet score kinetics for irradiated cells and non-irradiated ones in presence of $5 \cdot 10^{-5} \mathrm{Mg} / \mathrm{ml}$ of ethidium bromide. If in both cases we deal with the relaxed loops (the relaxation is due to either single-strand breaks or intercalation), then why does DNA of irradiated cells exits faster? An explanation might be that the irradiation induces some amount of double-strand breaks. Therefore, linear DNA (disrupted loop) goes faster through agarose. Although this possibility should not be rejected it has to be emphasized that the applied dose of radiation is rather low. According to some estimations about 1000 single-strand breaks per cell are induced by $1 \mathrm{~Gy}$ [13], which is much lower than one break per loop. Another explanation of the difference between the effects of irradiation and intercalation may proceed from the assumption about 
wide supercoiling distribution of the loops and/or the cells. As a result, none of the ethidium bromide concentrations is able to relax whole DNA entirely, and single-strand breaks appear to be more efficient in relaxation of some fraction of the loops, which form the comet tail.

The presented above analysis of the comet score kinetics indicates that the torsional constraint in the DNA loops is an obstacle on the way of the comet formation: the loop extension resembles a spring extension by external forces. As it is known the disappearance of such a force causes a reverse contraction of the spring. Similarly, termination of electrophoresis has to cause a decrease in the comet score: the loops have to "jump back" under elastic forces. Obviously, such effect is not expected if the elastic torsional constraint does not appear: when the loops are relaxed either due to single-strand breaks or by ethidium bromide intercalation. As it was expected, we observed partial disappearance of the comets after switching off the electrophoresis (Fig. 3,b). As it is shown in the figure the comet score remains at practically the same maximal level for both irradiated cells and those in presence of $5 \cdot 10^{-5} \mu \mathrm{g} / \mathrm{ml}$ of ethidium bromide (at the relaxation point). For intact cells (without ethidium bromide) rather slow decrease of the comet score is observed. Probably, the DNA "spring" where structural transitions occur (see above) is not that strong. In the presence of $2 \cdot 10^{-4} \mu \mathrm{g} / \mathrm{ml}$ of ethidium bromide the comet score decreases very fast to some low level and then remains unchanged. This residual level of the comets approximately coincides with the one, maximally reached during electrophoresis with $3.5 \cdot 10^{-4} \mu \mathrm{g} / \mathrm{ml}$ of ethidium bromide. Respectively, at this dye concentration the comet score is practically unchanged after termination of the electrophoresis (Fig. 3, $a, b$ ).

Irreversibility of DNA exit from irradiated cells and presence of some fraction of the comets that do not disappear after termination of the electrophoresis in the non-irradiated samples with high concentrations of ethidium bromide, allows us to assume that these remaining comets are formed by the loops which have single-strand breaks (caused by physiological processes). Apparently, only such loops are able to exit from the cells during electrophoresis at very high dye concentrations.

The presented results definitely indicate that the comet tail during the single cell gel electrophoresis is formed due to DNA looping that is significantly facilitated by the relaxation of the torsional constraint. Moreover, quite unexpectedly (although it is obvious $a$ posteriori), such looping is reversible if some torsional constraint is presented in the extended loop.

The described approach gives a possibility to estimate the topological state of DNA in nuclei of different cells in different functional states. That can be achieved by the determination of the concentration of an intercalator that is the most effective in facilitation of the comet formation. On the other hand, the found effects allow us to suggest several improvements of the comet assay. Firstly, it seems obvious that the recording of the comet appearance kinetics, is more sensitive approach to detect even small number of single-strand breaks as compared to commonly used fixed electrophoresis time. Moreover, the kinetic measurements can be considered as one of the ways to standardize the comet assay, since it is not necessary to choose particular electrophoresis duration. Secondly, the assay in the presence of high intercalator concentrations allows one to estimate more adequately the level of DNA breaks: only the loops with the breaks (without topological limitations) will be responsible for the comet formation in this case. Finally, another very simple approach to detect the level of DNA damages can be suggested: it is sufficient to determine the comet score after incubation of the samples in the electrophoretic buffer following long electrophoresis in presence of high concentration of an intercalator.

\section{К. С. Афанасьєва, Т. О. Шувалова, М. О. Зажицька, А. В. Сиволоб}

Оборотність виходу петель ДНК при кометному електрофорезі ізольованих клітин

Резюме

Досліджено кінетику виходу ДНК при кометному електрофорезі ізольованих лімфоцитів людини. Електрофорез проводили за нейтральних рН у відсутності чи присутності різних концентрачій бромистого етидію. Продемонстрована залежність ефективності виходу ДНК від конщентраціі останнього свідчить про те, щзо хвіст комети являє собою розтягнуті в електричному полі петельні домени. За умови 
релаксаиіі петель вихід ДНК суттєво полегшується, а за збереження певного рівня торсійних напружень у витягнутій петлі спостерігається зникнення комет після вимкнення електричного поля. Обговорюються можливості використання виявлених ефектів для вдосконалення методики кометного електрофорезу.

Ключові слова: кометний електрофорез, петельні домени, бромистий етидій, торсійні напруження в ДНК.

\section{REFERENCES}

1. Olive P. L. The comet assay. An overview of techniques // Meth. Mol. Biol.-2002.-203.-P. 179-194.

2. Collins A. R. The comet assay for DNA damage and repair: principles, applications, and limitations // Mol. Biotechnol.2004.-26, N 3.-P. 249-261.

3. Mrller $P$. The alkaline comet assay: towards validation in biomonitoring of DNA damaging exposures // Basic and Clin. Pharmacol. and Toxicol.-2006.-98, N 4.-P. 336-345.

4. Cook P. R., Brazell I. A., Jost E. Characterization of nuclear structures containing superhelical DNA // J. Cell Sci.-1976.22, N 2.-P. 303-324.

5. Hartmann A., Agurell E., Beevers C., Brendler-Schwaab S., Burlinson B., Clay P., Collins A., Smith A., Speit G., Thybaud $V$., Tice R. R. Recommendations for conducting the in vivo alkaline comet assay // Mutagenesis.-2003.-18, N 1.P. 45-51.

6. Horvathova E., Dusinska M., Shaposhnikov S., Collins A. DNA damage and repair measured in different genomic regions using the comet assay with fluorescent in situ hybridization // Mutagenesis.-2004.-19, N 4.-P. 269-276.
7. Collins A. R., Dobson V. L., Dusinska M., Kennedy G., Stetina $R$. The comet assay: what can it really tell us? // Mutat. Res.-1997.-375, N 2.-P. 183-193.

8. Simpson R. T., Thoma F., Brubaker J. M. Chromatin reconstituted from tandemly repeated cloned DNA fragments and core histones: a model system for study of higher order structure // Cell.-1985.-42, N 3.-P. 799-808.

9. Bauer $W$., Vinograd J. Interaction of closed circular DNA with intercalative dyes II. The free energy of superhelix formation in SV40 DNA // J. Mol. Biol.-1970.-47, N 3.P. 419-435.

10. Sivolob A., De Lucia F., Revet B., Prunell A. Nucleosome dynamics II. High flexibility of nucleosome entering and exiting DNAs to positive crossing. An ethidium bromide fluorescence study of mononucleosomes on DNA minicircles // J. Mol. Biol.-1999.-285, N 3.-P. 1081-1099.

11. Benham C. J. Energetics of the strand separation transition in superhelical DNA // J. Mol. Biol.-1992.-225, N 3.- P. 835847.

12. Sivolob A., Prunell A. Nucleosome dynamics V. Ethidium bromide versus histone tails in modulating ethidium bromide-driven tetrasome chiral transition. A fluorescence study of tetrasome on DNA minicircles // J. Mol. Biol.-2000.- 295, N 1.-P. 41-53.

13. Mrller P. Assessment of reference values for DNA damage detected by the comet assay in humans blood cell DNA // Mutat. Res.-2006.-612, N 2.-P. 84-104.

UDC 577.323:576.08

Received 20.06.07 